\title{
Determinan Akuntabilitas Laporan Keuangan: Tinjauan Pada Kinerja dan Politik di Pemerintahan Daerah di Indonesia
}

\author{
Suryo Pratolo 1 \\ Fakultas Ekonomi dan Bisnis \\ Universitas Muhammadiyah \\ Yogyakarta, Indonesia \\ Email: suryo.umy@gmail.com
}

\author{
Febriana Diah Irmawati ${ }^{2}$ \\ Fakultas Ekonomi dan Bisnis \\ Universitas Muhammadiyah Yogyakarta, \\ Indonesia
}

\begin{abstract}
ABSTRAK
Penelitian ini menguji dan meninjau secara empiris pengaruh kinerja keuangan, politik dinasti, dan kinerja pemerintah daerah pada akuntabilitas pelaporan keuangan daerah. Penelitian ini menggunakan metode dokumentasi dengan data sekunder yang diambil dari sumber Badan Pemeriksa Keuangan Republik Indonesia (BPK RI) dan Kementerian Dalam Negeri. Alat uji analisis yang digunakan dalam penelitian ini adalah regresi linier berganda. Aspek kinerja keuangan, menunjukkan bahwa desentralisasi fiskal tidak mempengaruhi secara signifikan kepada akuntabilitas pelaporan keuangan daerah namun ditemukan hasil pengolahan yang menunjukkan adanya rasio ketergantungan yang berpengaruh negatif dan signifikan terhadap akuntabilitas dari pelaporan keuangan yang dihasilkan oleh pemerintah daerah tersebut. Dinasti politik tidak berpengaruh signifikan terhadap akuntabilitas pelaporan keuangan pemerintahan daerah. Hasil juga menunjukkan pengaruh positif signifikan kinerja pemerintah daerah pada akuntabilitas pelaporan keuangan pemerintahan daerah.
\end{abstract}

Kata Kunci: Kinerja Keuangan Pemerintahan; Dinasti Politik; Kinerja Pemda; Akuntabilitas Pemerintah pada Pelaporan Keuangan.

\section{Determinants of Accountability in Financial Statements: Overview of Performance and Politics in Local Government in Indonesia}

\section{ABSTRACT}

This study is reviewed and tested empirically the influence of financial performance, dynastic politics, and performance of local government on accountability of regional financial reporting. This study uses the documentation method with secondary data taken from sources of the Indonesian Supreme Audit Board (BPK RI) and the Ministry of Home Affairs. The analytical test tool used in this study is multiple linear regression. It was found that the fiscal decentralization did not significantly affect the accountability of regional financial reporting but it was found that processing results showed a dependency ratio that had a negative and significant effect on the accountability of financial reporting produced by the local government. In the aspect of political dynasties, this variable was found to have no significant effect on the accountability of regional government financial reporting. The results also showed a significant positive effect of local government performance on the accountability of local government financial reporting.

Keywords: $\quad$ Financial Performance; Political Dynasty; Performane of Local Government; Accountability of Financial Reporting in Local Governance

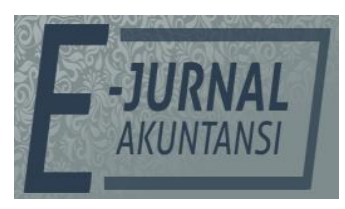

E-JA

e-Jurnal Akuntansi e-ISSN 2302-8556

Vol. 30 No. 3

Denpasar, Maret

2020

Hal. 800-814

Artikel Masuk:

8 Januari 2020

Tanggal Diterima: 12 Maret 2020 


\section{PENDAHULUAN}

Pada tahun 1998, Indonesia mengalami sejarah yang tidak terlupakan yaitu berakhirnya era orde baru dan dimulainya orde reformasi yang diiringi dengan selesainya pemerintahan di bawah pimpinan Presiden Suharto. Dalam tatakelola pemerintahan, orde baru dicirikan dengan sistem yang sentralistik dimana pada orde reformasi, sesuai tuntutan masyarakat mulai diubah dengan sistem yang terdesentralisasi. Pada era yang baru ini isu utamanya adalah reformasi birokrasi yang salah satunya adalah mengenai otonomi daerah, yaitu menyangkut kewenangan daerah untuk mengupayakan urusan pemerintahan sesuai dengan peraturan perundang-undangan di bawah Negara Kesatuan Republik Indonesia sesuai dengan aturan perundang-undangan.

Pendapat yang disampaikan oleh Syahrudin (2006) terkait berbagai permasalahan mengenai otonomi daerah, mayoritas disebabkan adanya kapasitas dan kemampuan yang kurang seimbang antara satu daerah dengan daerah lain meliputi aspek finansial, prasarana, maupun sumber daya insani (Syahrudin, 2006). Pengelolaan keuangan pada pemerintahan daerah merupakan salah satu urusan yang dirasa membutuhkan perbaikan atau reformasi dalam sistem dan aspek tatakelolanya. Perbaikan tersebut bisa diwujudkan dengan adanya desentralisasi kewenangan pemerintahan dan kewenangan pengelolaan keuangan dari pusat kepada daerah. (Carnegie, 2005). Tujuan dari reformasi birokrasi tersebut adalah untuk mewujudkan good dan clean governance pada pemerintahan daerah yang selaras dengan penerapan konsep New Public Management (NPM).

Salah satu komponen dari good governance adalah akuntabilitas atau pertanggungjelasan. Dengan akuntabilitas tentunya akan menjadikan pelayanan publik menjadi semakin baik karena pemerintahan yang memiliki akuntabilitas yang tinggi akan mendapat dukungan positif dari publik sehingga bisa terwujud kepercayaan masyarakat terhadap penyelenggaraan pelayanan publik. Akuntabilitas sangat terkait dengan sejauhmana tingkat pengungkapan pelaporan keuangan pemerintah daerah yang dengan terwujudnya hal tersebut masyarakat memungkinkan untuk dapat melakukan pengawasan terhadap kinerja pemerintah daerah. Untuk menciptakan akuntabilitas dalam mengelola keuangan daerah, peraturan perundangan yaitu undang-undang no. 17/2003 tentang Keuangan Negara dan undang-undang no. 32/ 2004 tentang Pemerintahan Daerah telah memberikan aturan dan ketentuan mengenai hal tersebut yang merupakan upaya nyata untuk mewujudkan transparansi dan akuntabilitas pengelolaan keuangan pemerintah daerah dengan adanya kewajiban untuk menyampaikan pelaporan keuangan daerah. Pemerintah daerah perlu melakukan pengelolaan keuangannya yang memenuhi prinsip akuntabilitas dan prinsip transparansi sebagai komponen dari good government governance. Sebagai bentuk pertanggungjelasan, pelaporan keuangan pemerintah darah diperiksa oleh pemeriksa eksternal dalam hal ini Badan Pemeriksa Keuangan (BPK) seiap tahun. Penyusunan laporan keuangan dan pemeriksaan atau pengawasan terhadap pellaporan keuangan pemerintah daerah merupakan upaya mewujudkan transparansi, akuntabilitas, dan pertanggungjawaban pemerintahan daerah. 
Kapucu (2009) menjelaskan bahwa penerapan Good Government Governance harus meliputi upaya perwujudan transparansi, akuntabilitas, dan partisipasi dalam menyelenggarakan kepemerintahan. Temuan dari peneliti Crawford \& Hermawan (2009) menyatakan bahwa penerapan good governance dilakukan dengan berbagai tahapan, yaitu: Penilaian dalam bentuk Evaluasi pada Penyelenggaraan Pemerintahan Daerah yang merujuk pada mendasarkan pada Peraturan Pemerintah No. 6/2008 dan Laporan Penyelenggaraan Pemerintah Daerah (LPPD). LPPD berisikan info mengenai semua aspek dalam pelaksanaan tugas yang harus dilaksanaan oleh pemerintah meliputi desentralisasi, tugas pembantuan, ataupun tugas pemerintahan secara umum (PP No.3/2007). LPPD disusun menggunakan prinsip transparansi dan akuntabilitas yang bisa digunakan sebagai proses penilaian pengelolaan pemerintahan.

Menurut Syahrudin (2006) desentralisasi fiskal merupakan salah satu fakor untuk terwujudnya akuntabilitas. Hal terebut karena dengan adanya desentralisasi fiskal, dimana pemerintah menjadi mampu meningkatkan kemampuan ekonomi, efisiensi, efektivitas, transparansi, dan akuntabilitas atas pengelolaan keuangan daerah (Moisiu, 2013). Apabila dilihat dari sumber lain, pada pemerintahan negara lain ditemukan level kejahatan korupsi yang semakin meninggi dengan penerapan desentralisasi fiskal (Moisiu, 2013). Sementara dari pendapat lain yaitu Maria et al, (2019); Rahayuningtyas \& Setyaningrum, (2017); Rinaldi, et al, (2007), bahwa di Indonesia ada kecenderungan korupsi di daerah dengan adanya desentralisasi fiskal tersebut. Hasil riset serupa dinyatakan oleh Liu (2007) yang menemukan bahwa pengaruh negatif dari desentralisasi fiskal adalah menaikkan tingkat korupsi dan tidak adanya perbaikan kualitas pelayanan kepada masyarakat. Hasil penelitian Puspasari dan Suwardi (2016) menunjukkan bahwa meskipun desentralisasi fiskal menjdikan daerah lebih fleksibel dan responsif dalam pelayanan publik, namun kebijakan ini memunculkan adanya praktik korupsi di pemerintah daerah.

Dalam penerapan desentralisasi fiskal di Indonesia, ada satu prinsip yang harus diwujudkan yaitu otonomi seluas-luasnya dimana pemerintah pusat memberikan kewenangan kepada pemerintahan yang ada di daerah dalam melaksanakan fungsi pelayanan publik dan membangun daerah. Pemerintah pusat membolehkan pendapatan dikelola oleh pemerintah daerah untuk secara optimal sehingga bisa membayar kebutuhan daerahnya. Selain pendapatan asli daerah, pemerintah pusat juga memberikan pendanaan kepada pemerintah daerah berupa dana perimbangan yang dapat dikelola daerah dalam pembiayaan penyelenggaraan pemerintahan daerah. Tujuan dari pemberian dana perimbangan yaitu dalam rangka mengatasi ketimpangan fiskal yang tinggi antara pemerintah pusat dan antar pemerintah daerah. Untuk meminimalisir adanya kebergantungan pemerintah daerah pada pemerintah pusat dari dana perimbangan tersebut, pada era reformasi, pemerintah daerah dituntut untuk mampu melakukan optimasi penggalian potensi pendapatan asli daerah yang menjadi tanggungjawabnya.

Dalam praktiknya, apa yang diinginkan dengan desentralisasi fiskal dan desentralisasi kekuasaan memiliki tantangan dan tidak bisa berjalan dengan mudah. Pemilihan kepala daerah secara langsung oleh rakyat pada awalnya ditujukan untuk mampu mendorong kemajuan daerah ternyata tidak 
sepenuhnya mulus berjalan. Dengan system pemilihan kepala daerah yang ada, membuka peluang munculnya fenomena "politik dinasti" yang menyebabkan entitas demokrasi berada di tempat yang rentan (Choi, 2009). Mnculnya politik dinasti merupakan ancaman pada tujuan dan proses demokrasi serta upaya pembangunan ekonomi pada rentang waktu panjang (Querubin, 2015). Hal lain yang muncul adalah kecenderungan eksekutif yang lebih kuat dari legislatif dan kemudian berdampak pada lemahnya check and balance (Nuritomo \& Rossieta, 2014). Hal ini dikarenakan berdasarkan peraturan perundangan kepala daerah tidak memiliki kewajiban tanggung jawab kepada legisatif karena kepaa daerah dipilih secara langsung rakyat. Menurut Nuritomo dan Rossieta (2014) suatu bangsa yang tingkat pendidikan penduduknya rendah secara rata-rata dan kemiskinannya pada tingkat atas, politik dinasti beresiko untuk muncul dan mendistorsi proses demokrasi.

Pada saat ini, pemilihan kepala daerah yang dilaksanakan secara langsung bisa menjadi salah satu penyebab munculnya politik dinasti. Menurut Asako et al. (2010) politik dinasti adalah jika kepala daerah mendapatkan kedudukan berupa pejabat publik dari kolega atau keluarganya yang dahulu berkuasa. Querrubin (2015) memandang politik dinasti dengan suatu definisi yang dapat diartikan sebagai kondisi dimana keluarga mendominasi adanya distribusi kekuasaan.

Permasalahan politik dinasti ini telah menjadi perhatian yang cukup besar yang pernah terjadi di beberapa pemerintah daerah, sehingga peneliti tertarik untuk melakukan penelitian berkaitan tentang politik dinasti tersebut. Ada banyak pendapat yang tidak positif tentang adanya perpolitikan yang diwariskan atau dinasti ini yang perlu untuk diuji lebih jauh. karenanya riset ini menguji hubungan antara praktik politik dinasti dengan akuntabilitas dan performan finansial pemerintah daerah dilakukan, dimana peneliti menguji tentang aspek Pelaporan Keuangan Daerah pada akuntabilitasnya yang dipengaruhi oleh kinerja pada aspek Keuangan, Perpolitikan secara Dinasti, dan Kinerja dari Pemerintah Daerah. Riset yang dilakukan ini mengadopsi penelitian Amy Fontanella \& Hilda Rossieta (2014). Adapun variabel pada penelitian ini adalah Tingkat dari Akuntabilitas atas Pelaporan Keuangan dari Pemerintahan Daerah. Ada perubahan variabel, dimana dari penelitian atas desentralisasi fiskal diganti menjadi kinerja keuangan. Variabel Politik secara Dinasti dan Kinerja dari Pemerintah Daerah yang digunakan pada riset ini diadopsi dari penelitian Nuritomo \& Hilda Rossieta (2014). Variabel kinerja pemerintah daerah diukur dengan Kinerja Penyelenggaraan Pemerintah Daerah yang dikeluarkan oleh Kemendagri. Penelitian ini juga merujuk pada penelitian di Amerika oleh Bojanic (2018) yang menemukan dampak desentralisasi fiskal pada kebebasan ekonomi, bagaimanapun, bertentangan dengan harapan. Desentralisasi pada awalnya tampaknya mendukung kebebasan, tetapi pada akhirnya menghambatnya, membuktikan bahwa akuntabilitas yang lebih besar dan kebebasan politik dan sipil tidak selalu mengarah pada kebebasan ekonomi yang lebih besar.

Teori yang menjadi landasan utama penelitian ini adalah teori keagenan dan teori stewardship. Teori keagenan adalah teori yang menjelaskan adanya hubungan antara pihak yeng memberikan amanah (principal) dengan pihak yang diberi amanah (agent). Hubungan principal-agent merupakan aspek yang bisa 
memunculkan asymmetry information karena agent menguasai lebih banyak informasi sedangkan principal lebih sedikit. Adanya informasi yang asimetri akan menjadikan agen terdorong menjadikan informasi tersembunyi, khususnya informasi yang tidak diketahui principal dimana situasi ini dinamakan dengan adverse selection. Dalam kondisi adverse selection ini bisa terjadi moral hazard oleh agent jika agent yang bisa menjadikan informasi akuntansi yang keliru yang disajikan dalam laporan keuangan untuk kepentingannya tanpa bertanggungjawab.

Problematika agensi juga bisa terjadi pada suatu organisasi pemerintahan yang mana adanya hubungan keagenan antara principal yaitu rakyat dengann agent yaitu pemerintah yang dalam perundangan Pemerintah Daerah. Pada aturan perundangan tersebut dinyatakan bahwa kepala daerah memiliki tanggung jawab kepada rakyat yang memilihnya atas proses merencanakan, melaksanaan dan mempertanggungjawaban program pemerintah. Jika dilihat posisinya, legislatif atau Dewan Perwakilah Rakyat Daerah (DPRD) DPRD analog dengan komisaris yang ditunjuk atau pilihan pemegang saham sebagai perwakilannya. Pemiliha yang bersifat demokratis sesuai dengan perundangundangan diharapkan mampu meningkatkan kinerja pemerintah sebagai agent dalam meningkatkan kesejahteraan rakyat selaku principal ada suatu masalah, yang antara laian merupakan problem politik secara dinasti (Nuritomo \& Rossieta, 2014).

Teorema stewardship atau penatalayan mengadung fondasi sosiologis dan psikologis dimana memandang para pemerintah adalah steward yang memiliki motivasi untuk melakukan tindakan sesuai apa yang diinginkan oleh principal, selain bahwa steward tidak akan lari dari organisasinya karena sebagai steward seseorang berupaya mewujudkan tujuan dari organisasinya. Asumsi dari teori ini adalah bahwa manusia pada hakikatnya mampu bertindak dengan penuh tanggung jawab, dapat dipercaya, berintegritas tinggi dan memiliki kejujuran. Teori stewardship adalah teori yang menggambarkan situasi dimana para lebih termotivasi tujuan-tujuan untuk kepentingan organisasi daripada kepentingan individunya,

Berlandaskan teori-teori tersebut, dengan adanya otonomi daerah dimana pemerintah daerah diberikan kewenangan untuk mengatur urusan pemerintahannya sendiri dengan dukungan dana dari pemerintah pusat sangat penting untuk bisa mewujudkan akuntabilitas pengelolaan keuangannya karena untuk menciptakan tingkat kepercayaan yang tinggi dari masyarakatnya. Akuntabilitas akan mampu menurunkan konflik keagenan dan pada waktu yang sama akuntabilitas menunjukkan adanya fungsi stewardship yang baik. Akuntabilitas merupakan hal utama dalam desentralisasi fiskal karena adanya perpindahan kewenangan keuangan daeri pemerintah pusat kepada pemerintah daerah, dimana jika otonomi daerah tidak diikuti oleh akuntabilitas maka yang terjadi adalah risiko korupsi yang berpindah dari pemerintah pusat ke pemerintah daerah. Penelitian Kusuma (2016) dan Hadi (2009) menjelaskan bahwa pada bangsa Indonesia, desentralisasi secara fiskal menaikkan efisiensi layanan masyarakat dan menumbuhkan ekonomi melalui perwujudan akuntabilitas publik. Pendapat lain adalah bahwa melalui akuntabilitas publik, pembiayaan dari pemerintah yang tidak lebih dari yang seharusnya dan adanya 
subsidi antara pemerintah pusat dan daerah dengan tujuan yang baik ternyata mempunyai hubungan yang positif dan kuat terhadap pertumbuhan (Yushkov, 2015).

Dari penjelasan tersebut dapat dilihat bahwa kemadirian kewenangan dalam pengelolaankeuangan daerah meewati desentralisasi fiskal seharusnya memiliki efek positif pada akuntabilitas keuangan. Berdasarkan penjelasan tersebut, maka bisa diajukan hipotesis pertama sebagai berikut.

$\mathrm{H}_{1}$ : Terdapat pengaruh Tingkat kemandirian daerah terhadap tingkat akuntabilitas pelaporan keuangan secara positip.

Menurut Abdul Halim (2001), bahwa ciri daerah yang mampu melakukan pendesentralisasian dengan baik artinya daerah tersebut mampu mencari sumber finansial, memanage dan memakainya dalam rangka membayar penyelenggaraan urusan pemerintahan dan untuk mengurangi atas ketergantungan nya pada pemerintah nasional. Berdasarkan teori agensi, pendesentralisasian fiskal akan memunculkan hubungan keagenan antara pemerintah pusat dengan pemerintah daerah yang bisa menjadikan kualitas pengelolaan keuangan pemda mempunyai akuntabilitas yang tinggi. Pada kondisi desentralisasi fiskal, pemerintah nasional bisa dikatakan sebagai prinsipal dan pemerintah daerah sebagai agen, dimana jika pemerintah daerah yang memiliki kewenangan pada pengeloaan keuagan daerah maka pada pemerintah pusat akan melakukan pengawasan menggunakan instrumen regulasi, berupa peraturan perundangan tentanag pengelolaan keyangan dan pengwawasan dan pemeriksaan keuangan daerah yang memadai sehingga kemandirian pendanaan daerah. Diharapak dengan desentralisasi fiskal dapat meningkatkan kualitas pengelolaan keuangan pemerintah daerah dan mewujudkan akuntabilitas yang tinggi. Penelitian yang dilakukan oleh Fontanella \& Rossieta (2014) meneliti keterkaitan antara kebergantungan pada pemerintah pusat pada tingkat keakuntabilitasan pelaporan keuangan pemerintah daerah. Dari uraian di atas, hipotesa nomor ke dua yang dirumuskan yaitu:

$\mathrm{H}_{2}$ : Terdapat Pegaruh negatif Tingkat ketergantungan keuangan entitas pada tingkat akuntabilitas pelaporan keuangan secara signifikan.

Riset Asako et al., (2010), tentang kaitan perpolitikan secara dinasti dengan upaya peningkatan kondisi ekonomi menunjukkan politik dinasti memiliki potensi menghambat upaya pengembangan ekonomi dan menjadikan daya saing lemah. Penelitian tersebut mengemukakan bahwa wilayah di bawah kendali politisi yang menggunakan politik secara dinasti menjadi lemah efektifitasnya dalam membawa pembangunan ekonomi kepada masyarakat, walau ada pemeberian dana yang lebih dari pemerintah nasional. Mendoza et.al (2012) melakukan riset dan menyatakan bahwa politik secara dinasti tidak selamanya menghasilkan korelasi dengan kemiskinan tinggi. Dari penelitian tersebut juga tidak ada hubungannya dengan redahnya standar hidup atau rendahnya tingat pengembangan. Dengan adanya politik secara dinasti artinya juga mempersulit munculnya calon alternatif bagi rakyat karena politisi dinasti memiliki kesempatan yang lebih baik untuk memenangkan pemilu (Querubin, 2015). Kondisi tersebut menunjukkan bahwa politik dinasti cenderung 
memuncukan governance yang buruk dimana salah satu aspek governance adalah akuntabilitas. Dari uraian tersebut, hipotesis ketiga yang diajukan adalah

$\mathrm{H}_{3}$ : Terdapat Pengaruh negatif Praktik Politik Dinasti Terhadap tingkat Akuntabilitas Pelaporan Keuangan.

Berdasarkan pada penelitian Fontanella \& Rossieta (2014), ada hubungan positif kinerja pemerintahan daerah dengan akuntabilitas pelaporan keuangan. Dari riset Sofyani \& Akbar $(2013 ; 2015)$ menyatakan bahwa ketika kinerja suatu pemerintahan baik, maka terdapat kecenderungan untuk memberikan akuntabilitas yang baik. Pemerintah pusat melakukan penilaian penyelenggaraan pemerintahan yang menunjukkan adanya proses mengawasi secara kontinyu dan dilakukan pelaporan capaian kegiatan. Evaluasi kinerja dilakukan untuk dapat meningkatkan keefisienan, keefektifitasan, penghematan dan produktifitas di organisasi sektor publik (Mahmudi, 2007). Dengann kinerja hasil pemeriksaan dalam bentuk penilaian tersebut mendukung terwujudnya akuntabilitas. Mudhofar \& Tahar (2016) dan Mahmudi (2007) menyatakan bahwa tingkat keakuntabilitasan dapat diwujudkan dengan cara menyampaikan pelaporan kinerja. Li (2015) menyatakan bahwa pengukuran kinerja akan meningkatkan efisiensi penggunaan sumber daya dan efektivitas strategi sehingga penggunaan sumber daya memiliki akuntabilitas yang baik. Dengan demikian, hipotesis keempat yang diajukan adalah

$\mathrm{H}_{4}$ : Terdapat Pengaruh positif Kinerja Pemerintah Daerah terhadap Tingkat Akuntabilitas Pelaporan Keuangan.

Berdasarkan hipotesis yang diajukan, model penelitian sebagaimana disajikan di Gambar 1.

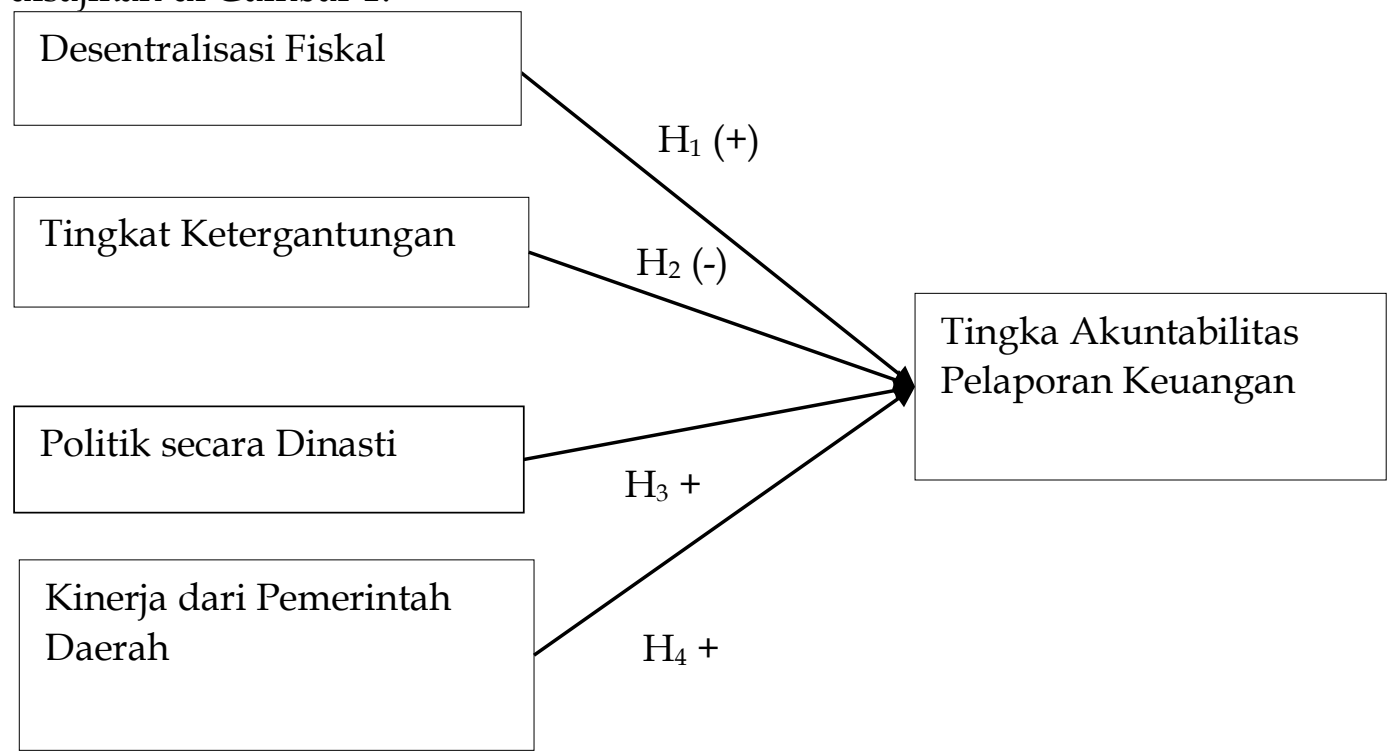

Sumber : Data Penelitian, 2019

Gambar 1. Disain Peneltian

\section{METODE PENELITIAN}

Objek dari riset ini adalah Pemerintah daerah di Kabupaten dan atau Kota di seluruh Indonesia untuk tahun 2012-2013. Pada penelitian ini, sampel yang digunakan adalah pemerintahan daerah baik kabupaten ataupun kota yang 
kepemimpinan daerahnya menjalankan praktik politik dinasti di Indonesia. Data yang digunakan pada penelitian ini adalah data sekunder yang bersumber dari Laporan Keuangan Pemerintah Daerah (LKPD Pemda) yang diaudit oleh Badan pemeriksa Keuangan Republik Inonesia (BPK RI) tahun anggaran 2012-2013. Data mengenai kondisi daerah yang mengalami politik dinasti bersumber dari Kementerian Dalam Negeri (Kemendagri). Untuk variabel kinerja pemda data yang digunaka bersumber pada Skor Evaluasi Kinerja Penyelenggaraan Pemerintahan Daerah (EKPPD). Skor tersebut didasarkan pada sumber dari Kementerian Dalam Negeri (Kemendagri). Sedangkan data hasil pendapat auditor didapatkan melalui hasil pemeriksaan setiap semester (IHPS) di paruh kedua pada tahun 2014 BPK RI.

Metode penyampelan dalam riset yang dilakukan ini adalah secara Purposive Sampling. Purposive Sampling adalah teknik penentuan sampel dengan kriteria tertentu. Kriteria sampel dalam riset ini yaitu pemerintahan daerah yang terindikasi menjalankan praktik politik dinasti. Metode Pengumpulan data yang digunakan dalam penelitian ini adalah dengan cara dokumentasi dan studi pustaka. Dokumentasi adalah suatu cara pengumpulan data dengan mengumpulkan dan mempelajari dokumen dari instansi yang bersangkutan. Dokumen yang dipakai pada penelitian ini adalah dokumen LKPD Pemda seluruh Indonesia tahun anggaran 2012-2013 yang resmi dikeluarkan oleh BPKRI, Data Pendapat Audit melalui ringkasan hasil pemeriksaan paruh 2 tahun 2014 yang resmi dikeluarakan oleh BPK-RI, data mengenai daerah yang ditengarai terjadi politik secara dinasti di Indonesia yang resmi dari Kementerian Dalam Negeri (Kemendagri) dan Skor EKPPD secara resmi didasarkan pada sumber Kementerian Dalam Negeri (Kemendagri).

Variabel Dependen dalam penelitian ini adalah akuntabilitas pelaporan keuangan daerah (Y). Akuntabilitas pelaporan keuangan daerah adalah pertanggungjawaban atas pelaporan keuangan. Variabel akuntabilitas pelaporan keuangan ini diproksikan dengan pendapat pemeriksaan yang dihasilkan oleh BPKRI, yaitu menggunakan penskalaan secara ordinal dari paling bawah sampai tinggi yaitu bahwa 1 artinya tidak menyatakan pendapat (TMP) , 2 artinya Tidak Wajar (TW) , 3 artinya Wajar Dengan Pengecualian (WDP) , dan 4 artinya Wajar Tanpa Pengecualian Dengan Paragraf Penjelas ( WTP-DPP) , $5=$ Wajar Tanpa Pengecualian (WTP). Untuk variabel independen dalam penelitian ini diantaranya adalah desentralisasi fiscal $\left(X_{1}\right)$, ketergantungan pada pemerintah pusat $\left(X_{2}\right)$, politik dinasti $\left(X_{3}\right)$, dan kinerja pemerintah daerah $\left(X_{4}\right)$.

Desentralisasi Fiskal adalah pemberiaan kewenangan pusat kepada daerah. Rasio Desentralisasi Fiskal dihtung dari Pendapatan (PAD) dibagi Total Pendapatan dikalikan $100 \%$. Ketergantungan pada pemerintah pusat adalah bagaimana pemerintah daerah mempunyai kemampuan keuangan daerah dalam membiayai pelaksanaan pemerintahan dan pembangunan.

Rasio ketergantungan pemda pada pemerintah pusat diukur dengan rumus:

(Dana Alokasi Umum (DAU) + Dana alokasi khusus (DAK))/ Pendapatan total dikalikan $100 \%$.

Politik dinasti adalah sebuah kekuasaan politik yang dijalankan oleh sekelompok orang yang masih terkait dalam hubungan keluarga. Variable ini 
diukur menggunakan angka 1 bagi daerah yang mana kepala daerahnya melakukan perpolitikan dinasti serta 0 untuk daerah yang kepala daerahnya tisak melakukan politik secara dinasti. Kinerja adalah prestasi yang telah diperoleh daerah dalam menjalankan pemerintahannya. Variable ini diukur dengan nilai kinerja penyelenggaraan pemerintahan daerah (EKPPD).

Tabel 1. Uji Statistik Deskriptif

\begin{tabular}{llllll}
\hline & $\mathrm{N}$ & Minimum & Maximum & Mean & $\begin{array}{l}\text { Std. } \\
\text { Deviation }\end{array}$ \\
\hline Desentralisasi_Fiskal & 114 & .8020 & $1.1347 \mathrm{E} 5$ & $1.010356 \mathrm{E} 3$ & $1.062575 \mathrm{E} 4$ \\
Ketergantungan & 114 & 1.1621 & 87.4325 & $5.840091 \mathrm{E} 1$ & 19.7399996 \\
Politik_Dinasti & 114 & .0000 & 1.0000 & .500000 & .5022075 \\
Kinerja_Pemda & 114 & .7198 & 3.2897 & $2.477049 \mathrm{E} 0$ & .5289085 \\
Akuntabilitas & 114 & 1.0000 & 5.0000 & $3.271930 \mathrm{E} 0$ & 1.0749364 \\
Valid N (listwise) & 114 & & & & \\
\hline
\end{tabular}

Sumber : Data Penelitian, 2019

Uji Statistik Deskriptif menunjukkan data yang dipakai pada riset berupa nilai min nilai maks, dan rerata (mean) serta nilai deviasi standar data. Untuk normalitas data menggunakan Tes Kolmogorov-Smirnov. Jika nilai probabilitas $>0,05$ maka model regresi memenuhi asumsi normalitas (Sugiyono, 2012). Data tidak memiliki nilai multikolinieritas ketika nilai cut-off yang menunjukkan nilai toleransi $>0,10$ atau sama dengan VIF < 10. (Ghozali, 2011). Dalam penelitian ini, peneliti melakukan uji autokorelasi dengan menggunakan uji Durbin-Watson (Uji DW). Penggunaan uji ini digunakan beberapa ketentuan untuk menentukan korelasi antara residual yaitu: (a) jikalau d lebih kecil dari dL atau lebih besar dari (4 - dL) maka hipotesis null ditolak, artinya terdapat autokorelasi. (b) jikalau d terletak antara dU dan $(4-\mathrm{dU})$, artinya hipotesis null diterima, berarti tidak terjadi autokorelasi. Sedangkan untuk mendeteksi asumsi Heteroskedastisitas digunakn uji Glejser untuk nilai absolut dari variabel residual hingga independen (Gujarati dalam Sari, 2006). Jika nilai sig $>0,05$ maka heteroskedastisitas tidak terjadi.

Penelitian ini menggunakan model rumus regresi berganda untuk melihat pengaruh dari variabel independen terhadap variabel dependen penelitian. Penelitian ini menggunakan regresi berganda karena variabel dependen diperngaruhi variable independen lebih dari satu. Rumus regresi linier berganda pada penelitian ini adalah :

$Y t=\beta 0+\beta 1 X 1+\beta 2 X 2+\beta 3 X 3+\beta 4 X 4$

Keterangan:

$\mathrm{Y}=$ Akuntabilitas Pelaporan Keuangan Daerah

$\beta 0 \quad=$ Konstanta

$\beta=$ Koefisien regresi linier $\mathrm{X}$

$\mathrm{X} 1=$ Desentralisasi Fiskal

$\mathrm{X} 2=$ Ketergantungan kepada Pemerintah Pusat

$\mathrm{X} 3=$ Politik Dinasti

$\mathrm{X} 4=$ Kinerja Pemerintah Daerah

$\mathrm{e} \quad=$ Error 
HASIL DAN PEMBAHASAN

Tabel 2. Uji Deskriptif Statistik

\begin{tabular}{llllll}
\hline Variable & $\mathrm{N}$ & $\mathrm{Min}$ & Max & Mean & $\begin{array}{l}\text { Std. } \\
\text { Deviation }\end{array}$ \\
\hline $\begin{array}{l}\text { Desentralisasi Fiskal } \\
\text { Ketergantungan Pemerintah }\end{array}$ & 114 & 0,802 & 1,135 & 1,010 & 1,063 \\
$\begin{array}{l}\text { Daerah } \\
\text { Politik Dinasti }\end{array}$ & 1,162 & 87,433 & 5,840 & 19,740 \\
Kinerja Pem Da & 114 & 0,000 & 1,000 & 0,500 & 0,502 \\
Akuntabilitas Pelaporan & 114 & 0,720 & 3,290 & 2,477 & 0,529 \\
\hline
\end{tabular}

Sumber : Data Penelitian, 2019

Berdasarkan hasil uji statisitik deskriptif dapat diketahui bahwa jumlah sampel $(\mathrm{N})$ berjumlah 114. Rata-rata dari data variabel desentralisasi fiskal diketahui adalah 1,010 dengan standar deviasi sebesar 1,063063. Pada data variabel ketergantungan pada pemerintah pusat rata-ratanya sebesar 5,840 dengan standar deviasi 19,740. Pada variabel politik dinasti rata-ratanya sebesar 0,500 dengan standar deviasi 0,502, pada variabel kinerja pemerintah daerah rata-ratanya sebesar 2,477 dengan standar deviasi 0,529 , selanjutnya adalah data pada akuntabilitas diketahui rata-rata 3,2722712 dan standar deviasinya adalah 1,075075 .

Berdasarkan nilai Sig hasil pengujian Kolmogorov-Smirnov dari nilai residual data yang digunakan dalam penelitian ini sebesar 0,073 , artinya lebih besar dari $5 \%$ atau 0,05. Temuan ini mengindikasikan bahwa pada tingkat komprehensif data penelitian yang digunakan sebagai sampel terdistribusi normal. Dalam uji multikolinearitas, dapat dilihat niali VIF pada seluruh variabel $<10$. Hasil temuan ini menunnjukan bahwa tidak terdapat multikolinearitas atau terdapat hubungan antara variabel independen. Uji autokorelasi menggunakan Durbin-Watson (DW) menunjukan nilai Durbin Watson yaitu sebesar 2,054, sedangkan nilai tabel pembanding bedasarkan data akunabilitas yaitu sebesar $\mathrm{dU}=1,768$, nilai $\mathrm{dU}<\mathrm{dW}<4$ maka 1,768 $<2,054<4$, sehingga dapat disimpulkan bahwa residual tidak mengandung autokorelasi. Hasil uji heteroskedastisitas dapat ditunjukkan setiap variabel pada model regresi memiliki nilai sig diatas $5 \%$ atau 0,05 . Hal ini menunjukan bahwa variabel yang dipakai pada model regresi atas riset ini tidak terjadi gejala heteroskedastisitas.

\section{Tabel 3. Hasil Uji Hipotesis}

\begin{tabular}{|c|c|c|c|c|}
\hline \multirow{2}{*}{ Variable } & \multicolumn{2}{|c|}{ Unstandarized Coefficient } & \multirow{2}{*}{$\begin{array}{l}\text { Standardize } \\
\text { Coefficient } \\
\text { Beta }\end{array}$} & \multirow{2}{*}{ Sig } \\
\hline & B & Std. Error & & \\
\hline (constant) & 3,207 & 0,570 & & 0,000 \\
\hline Desentralisasi Fiskal & $-2,792$ & 0,000 & $-0,028$ & 0,743 \\
\hline $\begin{array}{l}\text { Ketergantungan } \\
\text { Pemerintah Pusat }\end{array}$ & $-0,020$ & 0,005 & $-0,360$ & 0,000 \\
\hline Politik Dinasti & -0.321 & 0,181 & $-0,150$ & 0,079 \\
\hline Kinerja Pemerintah Daerah & 0,554 & 0,174 & 0,273 & 0,002 \\
\hline
\end{tabular}

Berdasarkan Tabel 2. variabel desentralisasi fiskal memiliki nilai koefisien regresi sebesar $-2,729$ dengan signifikansi $0,743>$ a 0,05 sehingga variabel desentralisasi fiskal tidak terbukti berpengaruh signifikan terhadap variabel 
akuntabilitas pelaporan keuangan pemerintah daerah. Jadi, hipotesis 1 tidak terdukung. Variabel ketergantungan pemerintah daerah kepada pada pemerintah pusat memiliki nilai sebesar -0,020 dengan signifikansi sebesar 0,000 $<$ a $(0,05)$ yang artinya variabel ketergantungan pemerintah daerah memiliki pengaruh negatif signifikan terhadap variabel akuntabilitas pelaporan keuangan daerah. Jadi, hipotesis 2 terdukung. Pada variabel politik dinasti memiliki koefisiensi sebesar -0,321 dengan signifikansi sebesar 0,079> a 0,05 sehingga variabel politik dinasti tidak terbukti berpengaruh signifikan terhadap variabel akuntabilita pelaporan keuangan daerah. Jadi, hipotesis 3 tidak terdukung. Sedangkan variabel kinerja pemerintahan daerah dengan koefisien 0,554 dan signifikansi $0,002<$ a 0,05 sehingga variabel kinerja pemerintah daerah terbukti berpengaruh positif dan sinifikan terhadap variabel akuntabilitas pelaporan keuangan pemerintah daerah. Jadi, hipotesis 4 terdukung.

Penelitian ini dilakukan untuk mengetahui pengaruh kinerja keuangan yang digambarkan dengan desentralisasi fiskal dan ketergantungan pada pemerintah pusat, serta variabel perpoltikan secara dinasti dan kinerja atau performan dari pemerintahan daerah serta tingkat akuntabilitas pelaporan keuangan daerah. Berdasarkan pengujian empiris yang telah dilakukan terhadap beberapa hipotesis dalam penelitian, hasilnya menunjukkan bahwa tidak semua variabel independen yang diteliti memiliki pengaruh signifikan terhadap variabel dependennya. Variabel-variabel yang berpengaruh positif dan signifikan terhadap tingkat keakuntabilitasan pelaporan keuangan daerah adalah kinerja atau performan dari pemerintahan daerah sedangkan yang berpengaruh negatif adalah ketergantungan daerah pada pemerintah pusat.

Berdasarkan hasil analisis pada hipotesis pertama kemandirian pemerintah daerah tidak memiliki pengaruh terhadap akuntabilitas pelaporan keuangan daerah secara signifikan. Hasil ini konsisten dengan penelitian Rinaldi (2007), tetapi bertentangan dengan penelitian Kusuma (2016) dan Hadi (2009) yang menjelaskan bahwa pada negara Indonesia, desentralisasi memunculkan keefisienan layanan masyarakat dan ekonomi tumbuh meningkat. Hasil ini berlawanan dengan logika peneliti bahwa dengan desetralisasi fiskal dapat meningkatkan kemandirian daerah karena daerah diberikan kebebasan dalam mengelola pendanaan, dengan tanggungjawab tersebut maka daerah akan transparan dan akuntabilitas terhadap pelaporan keuangan pemerintah daerah. Tapi dalam prakteknya, desentralisasi fiskal dengan ditunjuukan kebebasan dalam mengelola pendanaan atau keuangan daerah itu meningkatkan korupsi bukannya meningkatkan pelayanan masyarakat. Jadi, desentralisasi fiskal tidak terlalu berpengaruh terhadap akuntabilitas pelaporan keuangan pemerintah daerah karena mungkin ada manipulasi orang-orang tertentu untuk tujuan tertentu.

Berdasarkan hasil analisis pada hipotesis kedua menunjukan bahwa variabel ketergantungan pemerintah daerah menghasilkan pengaruh negatif pada akuntabilitas pelaporan finansial pemerintah daerah. Temuan ini berbeda jika dibandingkan dengan temuan riset Fontanella \& Rossieta (2014) dimana kebergantungan pemerintahan di daerah tidak mengindikasikan adanya pengaruh terhadap akuntabilitas pelaporan finansial pemerintah daerah. Apabila suatu pemerintah daerah telah melakukan dengan baik desentralisasi fiskalnya, 
berarti mampu dalam mendapatkan dan meingkatkan sumber keuangan, mengelolanya dan menggunakannya untuk membiayai penyelenggaraan pemerintah sehingga mengurangi ketergantungan pada pemerintah nasional (Halim, 2001). Secara ideal suatu desentralisasi fiskal didukung dengan paket aturan untuk mendukung pengelolaan keuangan daerah. Jika ketergantungan pemerintah daerah rendah bisa dikatakan pemerintah daerah yang bersangkutan mampu mandiri dalam mengelola keuangannya dan pelaporan keuangannya memiliki akuntabilitas yang tinggi.

Berdasarkan hasil analisis pada hipotesis ketiga menunjukan bahwa akuntabilitas pelaporan keuangan daerah tidak dipengaruhi variabel politik dinasti. Hasil ini berbeda dengan riset yang dilakukan oleh Asako et al., (2010). Asako menyatakan bahwa dinasti politik memiliki berpotensi menghambat pembangunan ekonomi dan melemahkan daya saing pemilu. Mereka mendapatkan temuan bahwasanya politisi dinasti pada daerah daerah kurang efektif dalam membawa pembangunan ekonomi bagi masyarakat, meskipun mereka menerima alokasi anggaran yang lebih dari pemerintah pusat. Hal tersebut dapat memengaruhi rendahmya tingkat akuntabilitas pelaporan keuangan pemerintah. Namun seperti yang ditemukan oleh Mendoza et. al (2012). Riset terebut menunjukkan bahwa aspek politik dinasti tidak selalu memiliki korelasi dengan kemiskinan yang tinggi, standar hidup yang rendah atau pembangunan manusia. Meskipun politik dinasti memiliki kesempatan lebih besar untuk memenangkan pemilu dibandingkan calon lain, namun tidak semua calon yang berlatar belakang politik dinasti berkulitas rendah dan tidak kompeten karena calon dari keluarga yang berlatar belakang politik dinasti sudah mengikuti dan memenuhi persyaratan sehingga layak untuk menjadi kepala daerah yang terpilih. sehingga politik dinasti tidak ada pengaruhnya terhadap akuntabilitas pelaporan keuangan pemerintahan daerah.

Berdasarkan hasil analisis pada hipotesa keempat menunjukan bahwa kinerja memiliki pengaruh signifikan positif pada aspek akuntabilitas pelaporan keuangan yang dihasilkan pemerintah daerah. Temuan dari penelitian ini selaras dengan penelitian Fontanella \& Rossieta (2014). Penelitian tersebut menyatakan bahwa ada pengaruh kinerja dalam penyelenggaraan pemerintah daerah dimana dimugkinkan daerah tersebut memiliki akuntabilitas pelaporan keuangan. Kinerja merupakan suatu capaian yang telah peroleh pemerintah daerah sehingga kinerja perlu dilakukan pengukuran. Adanya pengukuran kinerja secara selaras akan memberikan umpan balik yang baik sehingga terjadi upaya perbaikan yang berkelanjutan untuk mencapai tujuan dimasa yang akan datang (Bastian, 2016). Kinerja menggambarkan efisiensi, efektivitas, penghematan, dan produktivitas pemerintah daerah. Penyelenggaraan Temuan penelitian Riza, B.S (2015) menunjukkan bahwa sistem pengukuran kinerja yang baik memberikan gambar adanya orientasi pemda untuk mewujudkan good governance di pemerintahan (Mudhofar \& Tahar, 2016) akan memberikan manfaat berupa perencanaan kinerja (Riza, B. S., 2015). Akuntabilitas pelaporan keuangan pemerintah daerah meningkat apabila kinerja keuangan yang diperoleh pemerintah daerah juga meningkat. Hal tersebut menunjukan bahwa kinerja pemerintah daerah meningkat dalam hal pelayanan kepada masyarakat. 


\section{SIMPULAN}

Dengan menggunakan data sekunder dari Badan Pemeriksa Keuangan dan Kementerian Dalam Negeri penelitian ini menunjukkan simpulan-simpulan berikut. Simpulan pertama yang bisa dirumuskan adalah bahwa kemandirian daerah dalam penelitian ini tidak terbukti adanya pengaruh terhadap akuntabilitas pelaporan keuangan daerah secara signifikan, hal ini menunjukkan bahwa kemandirian daerah yang menjadi proksi terwujudnya desentralisasi fiskal belum diikuti dengan terwujudnya akuntabilitas yang merupakan pertanggungjelasan keuangan daerah dalam wujud pelaporan keuangan, hal tersebut bisa menjadi eksposure akan adanya permasalahan dalam pengelolaan keuangan daerahnya. Simpulan kedua memberikan temuan dimana variabel ketergantungan daerah menunjukkan pengaruh terhadap akuntabilitas pelaporan keuangan pemerintah daerah secara negatif, yang menunjukkan bahwa semakin rendah tingkat ketergantungan keuangan kepada pemerintah nasional menjadikan pemerintahan daerah menjadi makin mampu dalam mendorong sistem dan personilnya dalam mewujudkan kualitas pertanggungjelasan keuangannya secara baik. Ini menunjukkan bahwa otonomi daerah dengan desentralisasi fiskalnya diikuti dengan aturan erundangan dalam pengelolaan keuangan daerah untuk mewujudkan akuntabilitas pelaporan keuangan yang tinggi kepada publik. Simpulan ketiga adalah bahwa adanya perpolitikan secara dinasti tidak menjadikan adanya pengaruh yang signifikan terhadap akuntabilitas pelaporan keuangan oleh pemerintahan daerah yang menunjukkan bahwa tidak semua calon yang berlatar belakang politik dinasti memiliki kualitas yang rendah dan tidak memiliki kompetensi karena dimungkinkan calon dari keluarga yang berlatar belakang politik dinasti sudah mengikuti dan memenuhi persyaratan sehingga layak untuk menjadi kepala daerah yang terpilih. sehingga variabel politik dinasti tidak menunjukkan adanya pengaruh pada akuntabilitas dari pelaporan keuangan daerah. Kesimpulan ke empat menunjukkan bahwa kinerja mempengaruhi akuntabilitas pelaporan keuangan pemerintah daerah secara signifikan yang mana menunjukakan bahwasannya akuntabilitas pelaporan keuangan pemerintah daerah semakin meningkat jika kinerja keuangan yang diperoleh pemerintah daerah juga meningkat.

Ada terdapat keterbatasan dari penelitian ini yang meliputi antara lain: (1) dalam mengukur desentralisasi Fiskal proksi yang digunakan adalah Kemandirian dari Daerah dan Ketergantungan dari Daerah. Masukan kepada peneliti selanjutnya, riset sejenis dapat menggunakan proksi secara komprehensif mencakup ekonomi maupun politik agar dapat menjelaskan secara lebih akuran mengenai desetralisasi fiskal. (2), periodisasi dua tahun untuk pengamatan yaitu 2012-2013, hal tersebut menyebabkan terbatasnya cakupan perkembangan pendapat audit yang digunakan sebagai indikator akuntabilitas pelaporan keuangan pemda. Dari keterbatas tersebut bisa disarankan kepada riset selanjutnya untuk memperluas objek penelitian dan menambah periode penelitian secara lebih panjang agar hasilnya makin baik. 


\section{REFERENSI}

Asako. (2010). Dynastic Legislators: Theory And Evidence From Japan, Working Papers. Waseda University Organization for Japan-US Studies.

Bastian, I. (2006). Sistem Akuntansi Sektor Publik. Edisi 2, Jakarta: Salemba Empat.

Carnegie \& West . 2005. Making Accounting Accountable in the Public Sector. Critical Perspective on Accounting, 16, et905-928.

Choi, N. 2009. Democracy And Patrimonial Politics In Local Indonesia. Indonesia, $88,131-164$.

Crawford, G. \& Hermawan, P. Y. (2002). “Whose Agenda? Partnership and International Assistance to Democratization and Governance Reform in Indonesia". Contemporary Southeast Asia.

Dal Bo. (2009). Political Dynasties. Review of Economic Studies, 76(1), 115-142.

Fontanella, A. \& Rossieta, H. (2014). Pengaruh Desentralisasi Fiskal Dan Kinerja Terhadap Akuntabilitas Pelaporan Keuangan Pemerintah Daerah Di Indonesia. Simposium XVII Lombok.

Halim, A. (2001). Manajemen Keuangan Daerah. Yogyakarta. UPP AMP YKPN.

Hamzah, A. (2008). Pengaruh Belanja dan Pendapatan terhadap Pertumbuhan Ekonomi, Kemiskinan dan Pengangguran. Konferensi Penelitian. Jatim.

Kapucu, N. (2009). New Public Management and Governance Perspectives in Understanding Public Management. Public Administration Review.

Liu, C. H. (2007). What Type of Fiscal Decentralization System has better Performance. School of Public Policy.

Mandell, L. M. (1997). Performance Measurement And Management Tools In Nort Carolina Local Governance. Public Administration Quarterly, 21, 96.

Mardiasmo. (2002). Akuntansi Sektor Publik. Yogyakarta. Penerbit ANDI.

. (2006). Perwujudan Transparansi dan Akuntabilitas Publik Melalui Akuntansi Sektor Publik: Suatu Sarana Good Governance. Jurnal Akuntansi Pemerintahan, 2(1), 1-17.

- (2009). Otonomi dan Manajemen Keuangan Daerah Yogyakarta. Penerbit Andi.

Mahmudi. (2007). Manajemen Kinerja Sektor Publik. UPP STIM YKPN. Yogyakarta.

McCoy, A. (2009). An Anarchy of Families: The Historiography of State and Family in the Philippines, in An Anarchy of Families: State and Family in the Philippines, ed. By A. McCoy: pp. 1-32. University of Wisconsin Press. Madison, WI.

Mimba, N. S. H (2007). Public Sector Performance Measurement in Developing Countries. Journal Of Accounting and Organizational Change, 3(3), 192-198.

Moisiu, A. (2013). Decentralizations and The Increased autonomy in Local Governments. Procedia-Social and Behavioral Sciences, 459-469.

Nuritomo \& Rossieta, H. (2014). Politik Dinasti, Akuntabilitas, Dan Kinerja Keuangan Pemerintah Daerah Di Indonesia, Simposium XVII Lombok.

Pemerintah Republik Indonesia Peraturan Pemerintah Nomor 3 Tahun 2007 tentang tentang Laporan Penyelenggaraan Pemerintah daerah kepada Pemerintah, Laporan Keterangan Pertanggungjawaban Kepala Daerah kepada Dewan Perwakilan Rakyat Daerah, dan Informasi Laporan Penyelenggaraan Pemerintahan Daerah kepada Masyarakat.

Pemerintah Republik Indonesia Peraturan Pemerintah Nomor 6 Tahun 2008 tentang Pedoman Evaluasi penyelenggaraan Pemerintah Daerah. 
Querrubin, P. (2010). Family and Politics: Dynastic Persistence in the Philippines. Working Paper. Massachusetts Institute of Technology.

Republik Indonesia. Undang-Undang No. 22 Tahun 1999 Tentang Pemerintah Daerah

Republik Indonesia. Undang-Undang No. 25 Tahun 1999 Tentang Perimbangan keuangan antara pemerintah pusat dan daerah 